University of Nebraska - Lincoln

DigitalCommons@University of Nebraska - Lincoln

2012

\title{
Habitat fragmentation effects on annual survival of the federally protected eastern indigo snake
}

D. R. Breininger

Kennedy Space Center, david.r.breninger@nasa.gov

Marc J. Mazerolle

Université du Québec en Abitibi-Témiscamingue, marc.mazerolle@uqat.ca

M. R. Bolt

Kennedy Space Center

M. L. Legare

U. S. Fish and Wildlife Service

J. H. Drese

Kennedy Space Center

See next page for additional authors

Follow this and additional works at: https://digitalcommons.unl.edu/nasapub

Breininger, D. R.; Mazerolle, Marc J.; Bolt, M. R.; Legare, M. L.; Drese, J. H.; and Hines, J. E., "Habitat fragmentation effects on annual survival of the federally protected eastern indigo snake" (2012). NASA Publications. 106.

https://digitalcommons.unl.edu/nasapub/106

This Article is brought to you for free and open access by the National Aeronautics and Space Administration at DigitalCommons@University of Nebraska - Lincoln. It has been accepted for inclusion in NASA Publications by an authorized administrator of DigitalCommons@University of Nebraska - Lincoln. 


\section{Authors}

D. R. Breininger, Marc J. Mazerolle, M. R. Bolt, M. L. Legare, J. H. Drese, and J. E. Hines 


\title{
Habitat fragmentation effects on annual survival of the federally protected eastern indigo snake
}

\author{
D. R. Breininger ${ }^{1}$, M. J. Mazerolle ${ }^{2}$, M. R. Bolt ${ }^{1}$, M. L. Legare ${ }^{3}$, J. H. Drese ${ }^{1}$ \& J. E. Hines ${ }^{4}$ \\ 1 NASA Ecological Programs, Innovative Health Applications, Kennedy Space Center, FL, USA \\ 2 Centre d'étude de la forêt, Département des sciences appliquées, Université du Québec en Abitibi-Témiscamingue, Rouyn-Noranda, \\ QC, Canada \\ 3 Merritt Island National Wildlife Refuge, U. S. Fish and Wildlife Service, Titusville, FL, USA \\ 4 Patuxent Wildlife Research Center, United States Geological Survey, Laurel, MD, USA
}

\section{Keywords}

detectability; encounter probability; survival; multistate model; endangered species.

\author{
Correspondence \\ David R. Breininger, NASA Ecological Pro- \\ grams, IHA-300, Kennedy Space Center, \\ FL 32899, USA. Tel: +1 321476 4128; \\ Fax: +1 3218592939 \\ Email: david.r.breninger@nasa.gov \\ Editor: Res Altwegg \\ Associate Editor: Benedikt Schmidt \\ Received 25 October 2011; accepted 16 \\ January 2012
}

doi:10.1111/j.1469-1795.2012.00524.x

\begin{abstract}
The eastern indigo snake (Drymarchon couperi) is a federally listed species, most recently threatened by habitat loss and habitat degradation. In an effort to estimate snake survival, a total of 103 individuals (59 males, 44 females) were followed using radio-tracking from January 1998 to March 2004 in three landscape types that had increasing levels of habitat fragmentation: (1) conservation cores; (2) conservation areas along highways; (3) suburbs. Because of a large number of radio-tracking locations underground for which the state of snakes (i.e. alive or dead) could not be assessed, we employed a multistate approach to model snake apparent survival and encounter probability of live and dead snakes. We predicted that male snakes in suburbs would have the lowest annual survival. We found a transmitter implantation effect on snake encounter probability, as snakes implanted on a given occasion had a lower encounter probability on the next visit compared with snakes not implanted on the previous occasion. Our results indicated that adult eastern indigo snakes have relatively high survival in conservation core areas, but greatly reduced survival in conservation areas along highways and in suburbs. These findings indicate that habitat fragmentation is likely to be the critical factor for species' persistence.
\end{abstract}

\section{Introduction}

Population size estimates provide little information for management without quantification of the factors that influence population numbers (Van Horne, 1983; Pulliam, 1988). Populations are particularly sensitive to habitat factors that affect breeder survival, but such vital rates are rarely estimated, particularly in ways that account for the confounding effects of detection probabilities (Conroy, 1993; Mazerolle et al., 2007; Breininger et al., 2009). Habitat fragmentation threatens biological diversity worldwide, and many snake species are likely to be sensitive to habitat fragmentation because they occur in low densities, have limited dispersal abilities, and are subject to direct and indirect mortality caused by humans (Webb \& Shine, 1998). Determining the severity, extent and cause of snake population declines is difficult because snake population parameters are difficult to quantify (Tuberville et al., 2000; Roe, Kingsbury \& Herbert, 2004; Altwegg et al., 2005; Roe, Gibson \& Kingsbury, 2006; Waldron et al., 2006; Winne et al., 2007; Hibbitts, Painter \& Holycross, 2009). Snake survival can depend on many factors, such as body size, habitat, fire and drought. The eastern indigo snake (Dry- marchon couperi) is a federally protected species whose survival is probably vulnerable to habitat fragmentation (US Fish \& Wildlife Service, 1998; Dodd \& Barichivich, 2007).

The population ecology of the eastern indigo snake is difficult to study using standard herpetological field techniques because it is a wide-ranging habitat generalist occurring in low densities, and it has inactive periods spent within den sites such as gopher tortoise (Gopherus polyphemus) burrows, debris piles or dense vegetation (Hyslop et al., 2009c; Stevenson et al., 2009). The diurnal species is seldom captured in traps, making typical capture-recapture techniques for studying population abundance, survival and recruitment difficult (Williams, Nichols \& Conroy, 2002). Although eastern indigo snakes are rarely seen, they are docile and not difficult to capture by hand when observed on open ground, making it possible to study them using radio-tracking. Home range comparisons in landscapes varying in the degree of fragmentation indicate that indigo snakes often cross roads and enter areas where their survival is jeopardized, making survival estimation important (Breininger et al., 2011). Most radio-tracking studies rely on known-fate analytical methods (White \& Garrott, 1990; Winterstein, Pollock \& Bunck, 2001), but such methods are 
inappropriate for indigo snakes because it is often not possible to determine whether they are alive or dead when they are underground.

Our objective was to estimate indigo snake survival in landscape types with three increasing levels of habitat fragmentation. We hypothesized that survival decreases with increasing habitat fragmentation, particularly for males, which occupy large home ranges (Breininger et al., 2011). Because we often could not assess the state of snakes as alive or dead, we used multistate modelling to estimate apparent survival, as well as the encounter probability of live and dead snakes, and the effect of transmitter implantation on snake encounter probability.

\section{Materials and methods}

\section{Study area}

Study sites included conservation lands and suburbs in central Florida with natural communities dominated by scrub, pine flatwoods, marshes, hammocks and swamps that were interspersed within the home ranges of individual indigo snakes (Breininger et al., 2011). Indigo snakes in the northern part of their range are restricted to sand hills and adjacent wetlands, largely because they need gopher tortoise burrows as den sites during winter (Speake, McGlincy \& Colvin, 1981; Diemer \& Speake, 1983). Indigo snakes are diurnal and actively forage for a variety of vertebrate prey, which often include other snakes (Stevenson et al., 2010).

We overlaid individual indigo snake home ranges on land-cover maps and classified them into one of three types using data and methods described in Breininger et al. (2011). Indigo snake home ranges in conservation areas that were not intersected by highways were termed 'conservation core'. Indigo snake home ranges within conservation areas (i.e. areas without buildings) that were intersected by highways (primary roads) were termed 'conservation highway'. Home ranges intersected by roads and containing housing/ buildings were termed 'suburb.'

During this study, we captured 103 adult indigo snakes opportunistically by hand and by constant effort trapping from 1998 to 2002 (Breininger et al., 2011). A veterinarian anaesthetized and surgically implanted snakes with SB-2 radio transmitters (Holohil Systems, Ltd, Carp, ON, Canada). Transmitters ranged from 5.7 to $9.8 \mathrm{~g}$ and had 10-24-month lifespans. Surgical implantation procedures followed Reinert \& Cundall (1982) by implanting transmitters two-thirds of the way from the head into the coelomic cavity and threading the antenna subcutaneously anterior to the transmitter. Ten snakes were given an antibiotic combined with ivermectin during surgery. The use of ivermectin was discontinued once it was discovered that it eventually resulted in the snake's death. All snakes given ivermectin were excluded from analyses from the time the antibiotic was administered. We held the snakes in captivity for 3 days post-surgery, and then returned them to their capture locations. We attempted to recapture snakes prior to expected battery failure in order to have their transmitters replaced.
Each week, we tried to observe the snake or at least determine snake movement to establish if it was alive, unless it was underground (Breininger et al., 2011). This allowed us to pinpoint the location of each snake on aerial photographs or by global positioning systems. Occasionally, we triangulated individuals when they were located in areas with limited accessibility, such as on private property. We recaptured $93 \%$ of the snakes prior to transmitter battery failure to replace their radio transmitters and extend their tracking period for longer than 1 year, and we recaptured $38 \%$ of the snakes twice to extend their tracking periods for longer than 2 years.

Following release, individuals were located every week until the transmitter failed, or the snake disappeared or died. Transmitters appeared to last for their expected lifespan except for one batch of 12 transmitters that began expiring after 10 months. Once this was recognized, we discontinued their use and attempted to recapture all snakes with those transmitters 10 months after their implantation. We attempted to determine the cause of death of each snake found dead. Snakes found along roadsides were assumed to have been killed by motor vehicles. On most occasions, snakes were precisely located, but their state (alive or dead) could not be assessed because they were in dens. Based on more than 100 snakes followed over 5 years, not many ventured outside the home ranges that were established during the first year of tracking, and we observed few movements $>2 \mathrm{~km}$. Some of the areas adjacent to our study site were not accessible, so there were many censored events (snakes not seen or precisely located, and therefore, not known to be alive or dead). This rendered inappropriate known-fate models (Kaplan-Meier product limit estimators) frequently used with radio-tracking data (Pollock et al., 1989; White \& Garrott, 1990).

\section{Multistate analyses}

We used a multistate model with the $\varphi$ (survival-transition probabilities) parameterization to model $\phi_{i}^{r s}$, the probability that an animal alive in state $r$ at period $i$ survives to period $i+1$ and is found in state $s$ at that time, $p_{i}^{s}$ the probability that an animal in state $s$ at period $i$ is captured (Brownie et al., 1993; Williams et al., 2002). 'State' referred to whether the animal was observed as alive or dead each time it was located. In our application, the probability of survival was estimated by $\varphi_{i}^{\text {alive-alive }}$, the probability of being alive at time $i$ and staying alive until time $i+1$. We fixed the probability of $\varphi_{i}^{\text {dead-dead }}$ to 1 (i.e. once dead, a snake remains dead). This model shares similar assumptions to that of the Cormack-Jolly-Seber model, namely that marks are not lost (i.e. transmitters remain active until the end of the study), individuals are correctly identified, and that snakes behave independently of one another (see Brownie et al., 1993; Williams et al., 2002).

In our multistate analysis, a ' 0 ' indicated a snake was either not located or located but its state was unknown, a ' 1 ' indicated that the snake was known alive, and ' 2 ' indicated the snake was known dead. Individuals were removed from 
Table 1 Variables potentially influencing eastern indigo snake (Drymarchon couperi) apparent survival and encounter probabilities considered in the candidate multistate capture-recapture models

\begin{tabular}{|c|c|c|}
\hline Parameter & Grouping variable & Biological interpretation \\
\hline \multirow[t]{4}{*}{$\varphi$} & Landscape & Survival varies across landscape type \\
\hline & Sex & Survival varies between sexes \\
\hline & Landscape*sex & Survival of males versus females differs across landscape type \\
\hline & Season*sex & Survival of males versus females differs across season \\
\hline \multirow[t]{10}{*}{$p$} & TSI & Transmitter implantation influences encounter probability on next occasion \\
\hline & Sex & Encounter probability varies between sexes \\
\hline & State & Encounter probability varies across live and dead snakes \\
\hline & Season & Encounter probability varies across season \\
\hline & Landscape*TSI & $\begin{array}{l}\text { Encounter probability of snakes implanted versus not implanted on previous occasion varies across } \\
\text { landscape type }\end{array}$ \\
\hline & Landscape*sex & Encounter probability of males versus females varies across landscape type \\
\hline & Landscape*state & Encounter probability of live versus dead snakes varies across landscape type \\
\hline & Sex*TSI & Encounter probability of snakes implanted versus not implanted on previous occasion varies between sexes \\
\hline & Sex*season & Encounter probability of males versus females varies across season \\
\hline & State*TSI & $\begin{array}{l}\text { Encounter probability of live versus dead snakes depends on whether they were implanted on previous } \\
\text { occasion }\end{array}$ \\
\hline
\end{tabular}

TSI, time since transmitter implantation.

the study at the end of the transmitter life or when they were found dead. The complement of survival $\left(1-\varphi_{i}^{\text {alive-alive }}\right)$ included animals that became classified as known dead and animals that disappeared.

Our study period spanned 326 weeks, which would imply encounter histories consisting of a string of 326 characters. We opted for an alternative arrangement of the encounter histories to reduce the number of parameters in subsequent analyses. Because we did not suspect year-to-year differences in weekly survival of indigo snakes, but rather, seasonal effects, we started the encounter history of each snake in the first week of January of the year of its first release. The length of each encounter history was based on the snake having been followed for the longest period (in weeks) since the first week of January of the year of its first release. In our case, it spanned 189 weeks ( 3 years and 33 weeks). Thus, for each individual, we indicated whether it had been seen alive or dead, or had not been seen in each of the 189 weeks following its initial release. We treated snakes as if they had not been encountered if their status could not be assessed, for example, because they were underground. These locations were viewed as providing no information about the process being modelled (snake life-death).

We estimated the parameters of the multistate models by maximum likelihood with a modification of program SURVIV (White, 1983) by J. E. Hines. To facilitate convergence, we used relatively simple models to obtain initial parameter estimates for the more complex models. Given that the weekly survival of adult indigo snakes is typically high and not of direct interest, we converted the estimates to yearly survival by exponentiation (i.e. $\varphi^{52}$ ) and obtained variances for yearly survival with the delta method (Oehlert, 1992).

\section{Candidate models}

We built models to test the biological hypotheses that snake survival varies across landscape type, sex, season, the landscape type $\times$ sex interaction and the season $\times$ sex interaction (Table 1). Based on the literature, we predicted that apparent survival would be lowest for male snakes in the suburb (landscape $\times$ sex interaction) and lowest in summer (season $\times$ sex interaction, Dodd \& Barichivich, 2007). We combined each of these potential effects on survival with different sources of variation for the encounter probabilities including time since transmitter implantation (TSI, i.e. week following implantation or not), landscape type, sex, state (alive or dead), season or combinations thereof (Table 1).

We kept the number of parameters in each model to a minimum, recognizing that the amount of data we had was limited for multistate models that estimate many parameters. We modelled seasonal effects by constraining survival and encounter parameters for each season (i.e. weekly estimates within a given season had the same value). Further, we only considered simple interactions. We formulated three complex models instead of a single global model, each consisting of $\varphi$ (landscape*sex*season) with $p$ (landscape*sex*state*TSI), $p$ (season*landscape) or $p$ (season*sex). These complex models were used to assess model fit.

We assessed goodness-of-fit with the pooled $\chi^{2}$ of program SURVIV (White, 1983) and estimated c-hat as $\chi^{2} /$ degrees of freedom (d.f.). The model involving time since transmitter implantation on the probability of encounter, $\varphi$ (landscape*sex*season) $p$ (landscape*sex*state*TSI), fit the data well $\left(\chi^{2}=914.44\right.$, d.f. $=892, \quad P=0.2946$, c-hat $=1.02)$. The other two models defined by the alterna- 

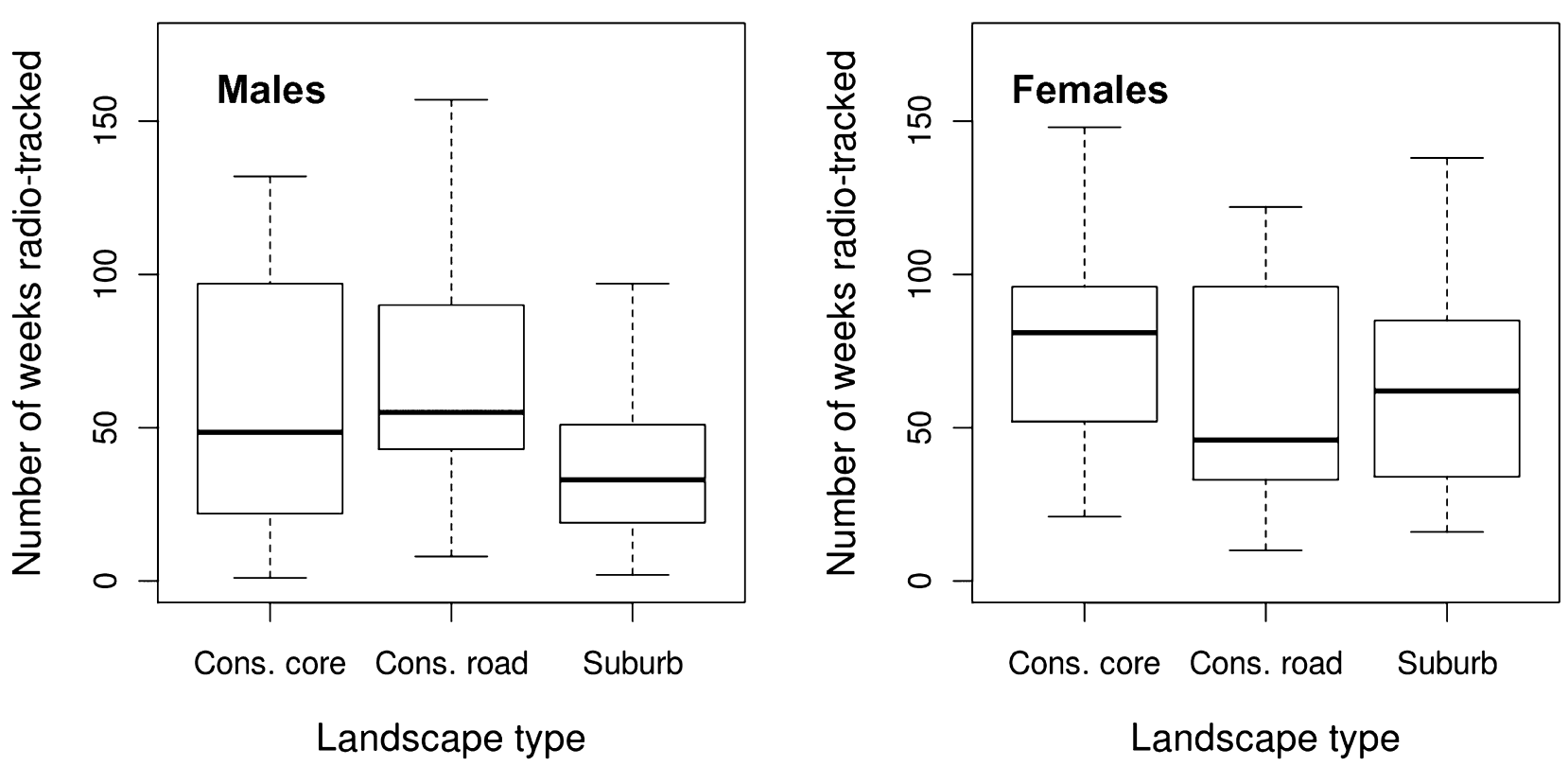

Figure 1 Number of weeks male and female eastern indigo snakes (Drymarchon couperi) were radio-tracked in habitats with different landscape types in Florida between 1998 and 2004. A total of 59 male snakes (26, 17 and 16 in conservation core, conservation road and suburb landscape types, respectively), and 44 female snakes (17, 13 and 14 in conservation core, conservation road and suburb landscape types, respectively) were implanted with transmitters and followed during the study. Note that upper and lower hinges of box plots indicate the first and third quartiles, and the median is the bold horizontal line within the box.

tive scenarios on encounter probability, $p$ (season*sex) and $p$ (season*landscape), did not fit the data. Model $\varphi$ (landscape*sex*season) $p$ (landscape*sex*state*TSI) yielded the smallest estimate of c-hat, and because it was very close to 1 , we used the second-order Akaike information criterion to select the most parsimonious of our candidate models (Burnham \& Anderson, 2002).

\section{Results}

Ninety-five per cent of our study animals were captured opportunistically. Female snakes $($ mean $=1.6 \mathrm{~m}$, range $=1.2-1.9 \mathrm{~m})$ averaged shorter than male snakes $($ mean $=1.7 \mathrm{~m}$, range $=1.3-2.1 \mathrm{~m})$, and female snakes (mean $1.2 \mathrm{~kg}$, range $=0.5-2.0 \mathrm{~kg}$ ) averaged lighter than male snakes $(1.5 \mathrm{~kg}$, range $=0.4-3.0 \mathrm{~kg})$. Fifty-one indigo snakes were alive at the end of the study when we terminated tracking, and 13 had disappeared without us being able to determine their fate (Fig. 1). We could not determine the cause of death for 11 snakes. We found 15 study animals dead along roads and five that were intentionally killed by humans. We observed one snake infested by intestinal, lung and external parasites that were the suspected cause of death. We believe that 10 snakes died from injections of ivermectin given during surgery. We observed one snake that may have died because of a leaking transmitter battery and no other problems caused by transmitters were observed by the veterinarian except those associated with ivermectin as described earlier.

There was strong evidence of variation of indigo snake apparent survival across landscape type. Model $\varphi$ (landscape) $p$ (landscape*TSI) ranked highest among the candi- date models with most of the support ( $w_{i}=0.90$, Table 2$)$. This model suggested that snake annual survival was highest in the conservation cores, and decreased with increasing habitat fragmentation (Fig. 2). Annual survival was higher in the conservation cores relative to conservation areas with roads [conservation core - conservation areas with roads $=0.26,95 \%$ confidence interval $(\mathrm{CI}): 0.017,0.499]$ and suburbs (conservation core - suburbs $=0.38,95 \%$ CI: 0.129 , 0.625). Survival of snakes between conservation areas with roads and suburbs was similar (conservation areas with roads - suburbs $=0.12,95 \% \mathrm{CI}$ : $-0.192,0.431)$. A second model had weak support for variations between male and female survival across landscape type, though this model had substantially lower weight $\left(w_{i}=0.09\right)$. There was no evidence supporting an effect of season on snake survival (Table 2).

Snake encounter probability varied across certain groups. Specifically, transmitter implantation had a negative effect on encounter probability, and this effect was relatively uniform within each landscape type (Fig. 3). The encounter probability of snakes in suburbs tended to be greater than in the other two landscape types (Fig. 3). However, there was no support in favour of encounter probabilities varying across snake state (live vs. dead), sex or season.

\section{Discussion}

Differences in survival between sexes can be substantial in some snake species (Bonnet, Guy \& Shine, 1999), but we did not find differences in annual survival between male and female snakes, which concurred with Hyslop et al. (2009b). 
Table 2 Top 10 multistate capture-recapture models for the radio-tracked eastern indigo snake (Drymarchon couperi) data following model selection based on the AICc

\begin{tabular}{|c|c|c|c|c|}
\hline Model & Log-likelihood & K & $\triangle \mathrm{AICC}$ & $w_{i}$ \\
\hline$\varphi$ (landscape) $p$ (landscape*TSI) & -2807.47 & 9 & 0 & 0.90 \\
\hline$\varphi$ (landscape*sex) $p$ (landscape*TSI) & -2806.70 & 12 & 4.55 & 0.09 \\
\hline$\varphi$ (landscape) $p$ (state $\left.{ }^{\star} \mathrm{TSI}\right)$ & -2816.79 & 6 & 12.58 & 0.00 \\
\hline$\varphi($ sex $) p$ (landscape*TSI) & -2816.77 & 8 & 16.57 & 0.00 \\
\hline$\varphi$ (landscape*sex*season) $p$ (landscape*sex*state*TSI) & -2775.22 & 48 & 16.64 & 0.00 \\
\hline$\varphi($ landscape*sex $) p\left(\right.$ state $\left.^{*} T S I\right)$ & -2815.79 & 10 & 18.66 & 0.00 \\
\hline$\varphi$ (season) $p$ (landscape*TSI) & -2816.00 & 10 & 19.08 & 0.00 \\
\hline$\varphi($ season*sex) $p$ (landscape*TSI) & -2815.15 & 14 & 25.52 & 0.00 \\
\hline$\varphi$ (landscape) $p$ (TSI) & -2825.28 & 5 & 27.54 & 0.00 \\
\hline$\varphi$ (landscape) $p$ (sex*TSI) & -2824.32 & 7 & 29.66 & 0.00 \\
\hline
\end{tabular}

AICc, the second-order Akaike information criterion; TSI, time since transmitter implantation.

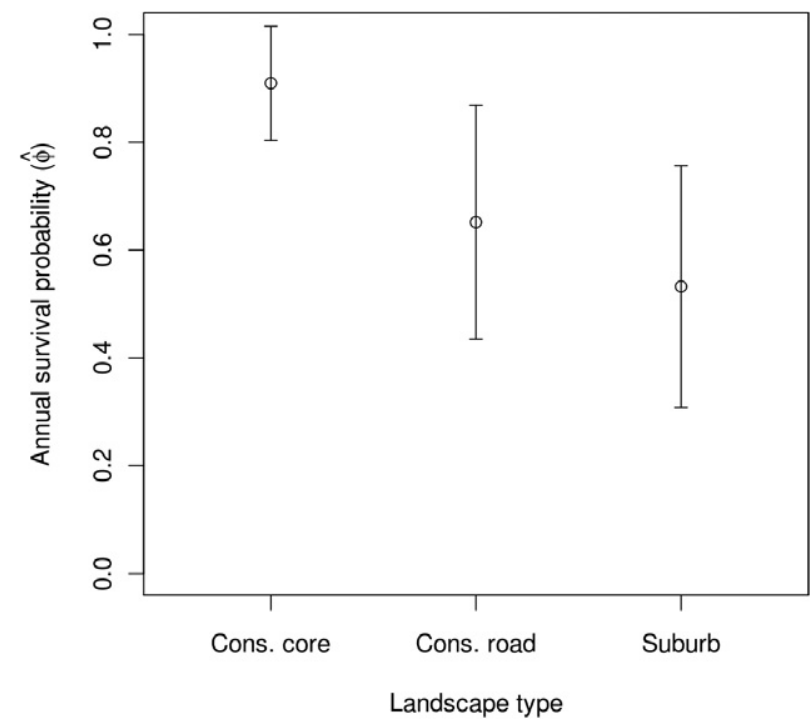

Figure 2 Annual apparent survival ( $\pm 95 \%$ confidence interval) of radio-tracked eastern indigo snakes (Drymarchon couperi) in Florida across the three landscape types. Estimates shown from the topranked multistate model, $\varphi$ (landscape) $p$ (landscape*time since transmitter implantation).

We found that at least $55 \%$ of known snake mortalities not associated with implantation procedure problems were caused by humans directly or indirectly along roads. We found little evidence for natural predation, probably because the snakes are relatively large predators themselves, and were often concealed in dense vegetation or underground. We found landscape-specific differences in survival, which are rarely investigated in vertebrates once potential differences in detection probabilities among landscape types are considered (Conroy et al., 1996; Breininger et al., 2009). The estimation of survival rates, while accounting for detection probabilities and other problems in data collection, is one of the most glaring deficiencies in snake population studies (Parker \& Plummer, 1987; Brown, Kery \& Hines, 2007; Hyslop et al. 2012).

For long-lived snakes, reduced survival may increase the extinction probability of populations (Webb, Brook \& Shine,

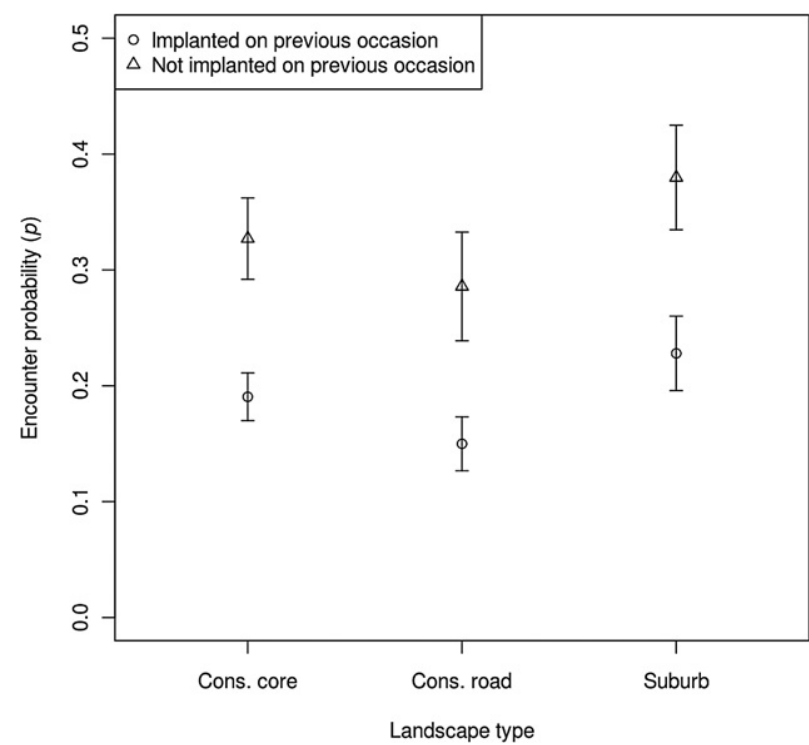

Figure 3 Encounter probability ( $\pm 95 \%$ confidence interval) of radiotracked eastern indigo snakes (Drymarchon couperi) in Florida across the three landscape types. Note that encounter probabilities for snakes implanted with a transmitter on the previous occasion were lower than for snakes not implanted on the previous occasion.

2002). Using population viability analyses, eastern indigo snake populations were predicted to be vulnerable to extinction in conservation areas bordered by roads and suburbs, based on survival rates similar to those reported in our study (Breininger, Legare \& Smith, 2004). Road mortality has particularly negative effects on herpetofauna and other animals that have large movement ranges, low reproductive rates and low natural densities (Fahrig \& Rytwinski, 2009). Direct killing by humans and road mortality have long been established as factors that make many large vertebrate species vulnerable to extinction in conservation areas with high edge to surface ratios (Woodroffe \& Ginsberg, 1998; Kerley et al., 2002; Schwartz, Haroldson \& White, 2010). Many studies show that edge to surface ratios are relevant to many herpetofauna and smaller vertebrate populations (Mumme et al., 2000; Driscoll, 2004; Balme, Slotow \& 
Hunter, 2010; McCall et al., 2010). Although roads often account for only a small portion of landscapes, their influence can extend across large areas because they restrict dispersal and gene flow (Trombulak \& Frissell, 2000; Forman et al., 2003; Shine et al., 2004; Steen \& Gibbs, 2004; Row, Blouin-Demers \& Weatherhead, 2007; Clark et al., 2010).

We suspect that indigo snakes could have higher survival in roadless conservation areas than observed in our study sites. All snakes occurred in areas that had at least some off-road vehicle traffic, and we recorded two snake deaths along roads only passable by off-road vehicles. It would be useful to repeat this study across a broad range of traffic volumes and road densities (e.g. Schwartz et al., 2010). Performing such a study is limited by the ability to capture enough study animals. We had success capturing study animals using traps designed by Rudolph et al. (1999). However, capture rates were low and traps had to be checked once or twice a day because of weather and the risk of capturing other protected species (Dyer, 2004).

Snake studies using telemetry usually rely on known-fate analyses, which was not appropriate in our study because we often could not determine if snakes underground were alive or dead. Combining radio-tracking methods with multistate capture-recapture analyses allowed us to reliably estimate survival for an animal that is rarely captured in traps, or whose fate often cannot be reliably determined even when an animal with a transmitter is located. We found one snake survival study that used multistate models, but such models were used in the conventional manner where the states referred to different habitats and not snake condition (live or dead; Lyet et al., 2009). A potential alternative to our approach would be to use multistate models with state uncertainty to exploit the information on underground locations (Nichols et al., 2004; Kendall, 2009). Although our study measured apparent survival and did not account for habitat-specific emigration, we never observed permanent emigration from home ranges between years or seasons (Breininger et al., 2011).

We agree with colleagues (Hyslop, 2007) that indigo snakes need large tracts of habitat for sustainable populations because individuals have large home ranges and are vulnerable to mortality caused by humans. Indigo snake populations, like many other species residing in firemaintained habitat, may themselves be influenced by fire history. Indeed, gopher tortoises require regular fires and these species provide necessary den sites for indigo snakes, at least in some portions of their range (Speake, McGlincy \& Colvin, 1978; Waldron, Welch \& Bennett, 2008; Hyslop, Cooper \& Meyers, 2009a).

\section{Conservation implications}

In this study, we showed that annual survival of indigo snakes decreased as levels of fragmentation increased to the extent that the viability of populations might be impacted. This reinforces our earlier argument that species conservation planning is needed to keep critical conservation areas from having too many edges that result in high indigo snake mortality (Breininger et al., 2004). Many existing conservation lands may be too small, especially if they become bordered by highways and suburbs. Conservation lands are often linked together to form larger systems, which is an excellent strategy when focusing on birds and vagile mammals. However, indigo snakes residing within corridors may be particularly vulnerable to extinction if they are too fragmented or too narrow. Corridors suitable for indigo snakes may need to be wider, unfragmented by roads and shorter than those needed for more vagile animals. In addition, all of our study animals were adults, there is a need for research to quantify how population vital rates are impacted by fragmentation of other life history stages (e.g. Hyslop et al. 2012) as younger animals may react differently to habitat perturbations.

\section{Acknowledgements}

The Bailey Wildlife Foundation, National Aeronautics and Space Administration, US Air Force, US Geological Survey, and Natural Sciences and Engineering Research Council of Canada funded this study. We thank G. Bailey, M. Bailey, J. Berish, P. Burger, C. Hall, R. Koester, L. LaClaire, P. Moler and R. Seigel. We also thank about 60 natural resource professionals that helped us capture indigo snakes for radio-tracking studies. J. D. Nichols provided constructive criticism on the manuscript and thoughtful advice on the modelling strategy.

\section{References}

Altwegg, R., Dummermuth, S., Anholt, B.R. \& Flatt, T. (2005). Winter weather affects asp viper Vipera aspis population dynamics through susceptible juveniles. Oikos 110, 55-66.

Balme, G.A., Slotow, R. \& Hunter, L.T.B. (2010). Edge effects and the impact of non-protected areas in carnivore conservation: leopards in the phinda-mkhuze complex, South Africa. Anim. Conserv. 13, 315-323.

Bonnet, X., Guy, N. \& Shine, R. (1999). The dangers of leaving home: dispersal and mortality in snakes. Biol. Conserv. 89, 39-50.

Breininger, D.R., Legare, M.L. \& Smith, R.B. (2004). Eastern indigo snakes: influence of edge effects on population viability. In Species conservation and management: case studies: 299-311. Akçakaya, H.R., Burgman, M.A., Kindvall, O., Wood, C.C., Sjorgren-Gulve, P., Hatfield, J.S. \& Mccarthy, M.A. (Eds). New York: Oxford University Press.

Breininger, D.R., Nichols, J.D., Carter, G.M. \& Oddy, D.M. (2009). Habitat-specific breeder survival of Florida scrub-jays: inferences from multistate models. Ecology 90, 3180-3189.

Breininger, D.R., Bolt, M.R., Legare, M.L., Drese, J.H. \& Stolen, E.D. (2011). Factors influencing home-range size of eastern indigo snakes in central Florida. J. Herpetol. 45, 484490 . 
Brown, W.S., Kery, M. \& Hines, J.E. (2007). Survival of timber rattlesnakes (Crotalus horridus) estimated by capture-recapture models in relation to age, sex, color morph, time, and birthplace. Copeia 2007, 656-671.

Brownie, C., Hines, J.E., Nichols, J.D., Pollock, K.H. \& Hestbeck, J.B. (1993). Capture-recapture studies for multiple strata including non-Markovian transitions. Biometrics 49, 1173-1187.

Burnham, K.P. \& Anderson, D.R. (2002). Model selection and multimodel inference: a practical information-theoretic approach. 2nd edn. New York: Springer-Verlag.

Clark, R.W., Brown, W.S., Stechert, R. \& Zamudio, K.R. (2010). Roads, interrupted dispersal, and genetic diversity in timber rattlesnakes. Conserv. Biol. 24, 1059-1069.

Conroy, M.J. (1993). Testing hypotheses about the relationship of habitat to animal survivorship. In Marked individuals in the study of bird population dynamics: 331-342. Lebreton, J.D. \& North, P.M. (Eds). Basel: BirkhauserVerlag.

Conroy, M.J., Anderson, J.E., Rathbun, S.L. \& Krementz, D.G. (1996). Statistical inference on patch-specific survival and movement rates from marked animals. Environ. Ecol. Stat. 3, 99-116.

Diemer, J.E. \& Speake, D.W. (1983). The distribution of the eastern indigo snake, Drymarchon corais couperi, in Georgia. J. Herpetol. 17, 256-264.

Dodd, C.K. Jr \& Barichivich, W.J. (2007). Movements of large snakes (drymarchon, masticophis) in north-central Florida. Fla. Sci. 70, 83-94.

Driscoll, D.A. (2004). Extinction and outbreaks accompany fragmentation of a reptile community. Ecol. Appl. 14, 220-240.

Dyer, K.J. (2004). Habitat use and seasonal activity of selected snakes on John F. Orlando: Kennedy Space Center. University of Central Florida.

Fahrig, L. \& Rytwinski, T. (2009). Effects of roads on animal abundance: an empirical review and synthesis. (Online) http://www.ecologyandsociety.org/vol14/iss1/ $\operatorname{art} 21$.

Forman, R.T.T., Sperling, D., Bissonette, J.A., Clevenger, A.P., Cutshall, C.C., Dale, V.H., Fahrig, L., France, R., Goldman, C.R., Heanue, K., Swanson, J.A., Turrentine, T. \& Winter, T.C. (2003). Road ecology: science and solutions. Washington, DC: Island Press.

Hibbitts, T.J., Painter, C.W. \& Holycross, A.T. (2009). Ecology of a population of the narrow-headed garter snake (Thamnophis rufipunctatus) in New Mexico: catastrophic decline of a river specialist. Southwest. Nat. 54, 461-467.

Hyslop, N.L. (2007). Movements, habitat use, and survival of the threatened eastern indigo snake (Drymarchon couperi) in Georgia. Athens, GA: University of Georgia.

Hyslop, N.L., Cooper, R.J. \& Meyers, J.M. (2009a). Seasonal shifts in shelter and microhabitat use of
Drymarchon couperi (eastern indigo snake) in Georgia. Copeia 2009, 458-464.

Hyslop, N.L., Meyers, J.M., Cooper, R.J. \& Norton, T.M. (2009b). Survival of radio-implanted Drymarchon couperi (eastern indigo snake) in relation to body size and sex. Herpetologica 65, 199-206.

Hyslop, N.L., Meyers, J.M., Cooper, R.J. \& Stevenson, D.J. (2009c). Indigo snake capture methods: effectiveness of two survey techniques for Drymarchon couperi in Georgia. Fla. Sci. 72, 93-100.

Hyslop, N.L., Stevenson, D.J., Macey, J.N., Carlile, L.D., Jenkins, C.L., Hostetler, J.A. \& Oli, M.K. (2012). Survival and population growth of a long-lived threatened snake species, Drymarchon couperi (eastern indigo snake). Popul. Ecol. 54, 145-156.

Kendall, W.L. (2009). One size does not fit all: adapting mark-recapture and occupancy models for state uncertainty. Environ. Ecol. Stat. 3, 765-780.

Kerley, L.L., Goodrich, J.M., Miquelle, D.G., Smirnov, E.N., Quigley, H.B. \& Hornocker, N.G. (2002). Effects of roads and human disturbance on Amur tigers. Conserv. Biol. 16, 97-108.

Lyet, A., Cheylan, M., Prodon, R. \& Besnard, A. (2009). Prescribed fire and conservation of a threatened mountain grassland specialist: a capture-recapture study on the Orsini's viper in the French alps. Anim. Conserv. 12, 238248.

Mazerolle, M.J., Bailey, L.L., Kendall, W.L., Royle, J.A., Converse, S.J. \& Nichols, J.D. (2007). Making great leaps forward: accounting for detectability in herpetological field studies. J. Herpetol. 41, 672-689.

Mccall, S.C., Mccarthy, M.A., Van Der Ree, R., Harper, M.J., Cesarini, S. \& Soanes, K. (2010). Evidence that a highway reduces apparent survival rates of squirrel gliders. Ecol. Soc. 15, 27.

Mumme, R.L., Schoech, S.J., Woolfenden, G.E. \& Fitzpatrick, J.W. (2000). Life and death in the fast lane: demographic consequences of road mortality in the Florida scrub-jay. Conserv. Biol. 14, 501-512.

Nichols, J.D., Kendall, W.L., Hines, J.E. \& Spendelow, J.A. (2004). Estimation of sex-specific survival from capturerecapture data when sex is not always known. Ecology 85, 3192-3201.

Oehlert, G.W. (1992). A note on the delta method. Am. Stat. 46, 27-29.

Parker, W.S. \& Plummer, M.V. (1987). Population ecology. In Snakes: ecology and evolutionary biology: 253-301. Seigel, R.A., Novak, S.S. \& Collins, J.T. (Eds). New York: MacGraw-Hill Book Company.

Pollock, K.H., Winterstein, S.R., Bunck, C.M. \& Curtis, P.D. (1989). Survival analysis in telemetry studies - the staggered entry design. J. Wildl. Manage. 53, 7-15.

Pulliam, H.R. (1988). Sources, sinks, and population regulation. Am. Nat. 132, 652-661. 
Reinert, H.K. \& Cundall, D. (1982). An improved surgical implantation method for radio-tracking snakes. Copeia 1982, 702-705.

Roe, J.H., Kingsbury, B.A. \& Herbert, N.R. (2004). Comparative water snake ecology: conservation of mobile animals that use temporally dynamic resources. Biol. Conserv. 118, 79-89.

Roe, J.H., Gibson, J. \& Kingsbury, B.A. (2006). Beyond the wetland border: estimating the impact of roads for two species of water snakes. Biol. Conserv. 130, 161-168.

Row, J.R., Blouin-Demers, G. \& Weatherhead, P.J. (2007). Demographic effects of road mortality in black ratsnakes (Elaphe obsoleta). Biol. Conserv. 137, 117-124.

Rudolph, C., Burgdorf, S., Conner, R. \& Schaefer, R. (1999). Preliminary evaluation of the impact of roads and associated vehicular traffic on snake populations in eastern Texas. In: Proceedings of the third international conference on wildlife ecology and transportation (FLER-73-99): 129-136. Evink, G. L., Garrett, P., Ziegler, D. (Ed.). Tallahassee, FL: Florida Department of Transportation.

Schwartz, C.C., Haroldson, M.A. \& White, G.C. (2010). Hazards affecting grizzly bear survival in the greater Yellowstone ecosystem. J. Wildl. Manage. 74, 654-667.

Shine, R., Lemaster, M., Wall, M., Langkilde, T. \& Mason, R. (2004). Why did the snake cross the road? Effects of roads on movement and location of mates by garter snakes (Thamnophis sirtalis parietalis). (Online) http:// www.ecologyandsociety.org/vol14/iss1/art21.

Speake, D.W., Mcglincy, J.A. \& Colvin, T.R. (1978). Ecology and management of the eastern indigo snake in Georgia: a progress report. In: Proceedings of rare and endangered wildlife symposium (Technical Bulletin WL4): 64-73. Odum, R. R., Landers, L. (Ed.). Athens: Georgia Department of Natural Resources, Game and Fish Division.

Speake, D.W., Mcglincy, J.A. \& Colvin, T.R. (1981).

Response of eastern indigo snakes to gassing their dens. Proceedings of the Annual Conference of Southeastern Association of Fish and Wildlife Agencies, 35: 135-138.

Steen, D.A. \& Gibbs, J.P. (2004). Effects of roads on the structure of freshwater turtle populations. Conserv. Biol. 18, 1143-1148.

Stevenson, D.J., Enge, K.M., Carlile, L.D., Dyer, K.J., Norton, T.M., Hyslop, N.L. \& Kiltie, R.A. (2009). An eastern indigo snake (Drymarchon couperi) markrecapture study in southeastern Georgia. Herpetol. Conserv. Biol. 4, 30-42.

Stevenson, D.J., Bolt, M.R., Smith, D.J., Enge, K.M., Hyslop, N.L., Norton, T.M. \& Dyer, K.J. (2010). Prey records for the Eastern Indigo Snake (Drymarchon couperi). Southeast. Nat. 9, 1-18.

Trombulak, S.C. \& Frissell, C.A. (2000). Review of ecological effects of roads on terrestrial and aquatic communities. Conserv. Biol. 14, 18-30.

Tuberville, T.D., Bode, J.R., Jensen, J.B., Laclaire, L. \& Gibbons, J.W. (2000). Apparent decline of the southern hog-nosed snake, Heterodon simus. J. Elisha Mitchell Sci. Soc. 116, 19-40.

US Fish \& Wildlife Service (1998). Multispecies recovery plan for the threatened and endangered species of South Florida. Atlanta, GA: USFWS.

Van Horne, B. (1983). Density as a misleading indicator of habitat quality. J. Wildl. Manage. 47, 893-901.

Waldron, J.L., Bennett, S.H., Welch, S.M., Dorcas, M.E., Lanham, J.D. \& Kalinowsky, W. (2006). Habitat specificity and home-range size as attributes of species vulnerability to extinction: a case study using sympatric rattlesnakes. Anim. Conserv. 9, 414 420.

Waldron, J.L., Welch, S.M. \& Bennett, S.H. (2008). Vegetation structure and the habitat specificity of a declining North American reptile: a remnant of former landscapes. Biol. Conserv. 141, 2477-2482.

Webb, J.K. \& Shine, R. (1998). Ecological characteristics of a threatened snake species, Hoplocephalus bungaroides (Serpentes, Elapidae). Anim. Conserv. 1, 185-193.

Webb, J.K., Brook, B.W. \& Shine, R. (2002). What makes a species vulnerable to extinction? Comparative lifehistory traits of two sympatric snakes. Ecol. Res. 17, 59-67.

White, G.C. (1983). Numerical estimation of survival rates from band-recovery and biotelemetry data. J. Wildl. Manage. 47, 716-728.

White, G.C. \& Garrott, R.A. (1990). Analysis of radiotracking data. New York: Academic Press.

Williams, B.K., Nichols, J.D. \& Conroy, M.J. (2002). Analysis and management of animal populations. New York: Academic Press.

Winne, C.T., Willson, J.D., Todd, B.D., Andrews, K.M. \& Gibbons, J.W. (2007). Enigmatic decline of a protected population of eastern kingsnakes, Lampropeltis getula, in South Carolina. Copeia 2007, 507-519.

Winterstein, S.R., Pollock, K.H. \& Bunck, C.M. (2001). Analysis of survival data from radiotelemetry studies. In Radio tracking and animal populations: 351-380. Millspaugh, J.J. \& Marzluff, J.M. (Eds). New York: Academic Press.

Woodroffe, R. \& Ginsberg, J.R. (1998). Edge effects and the extinction of populations inside protected areas. Science 280, 2126-2128. 